\title{
Contrasting Vegetation Gradient Effects Explain the Differences in Leaf Traits Among Woody Plant Communities in the Amazonia-Cerrado Transition
}

Igor Araújo ( $\square$ igor.araujo@outlook.com.br)

Universidade do Estado de Mato Grosso https://orcid.org/0000-0002-9226-7321

Marina C. Scalon

UFPR: Universidade Federal do Parana

Izabel Amorim

UNEMAT: Universidade do Estado de Mato Grosso

Imma Oliveras

University of Oxford

Wesley J. A. Cruz

UNEMAT: Universidade do Estado de Mato Grosso

Simone Matias Reis

UNEMAT: Universidade do Estado de Mato Grosso

\section{Beatriz S. Marimon}

UNEMAT: Universidade do Estado de Mato Grosso

\section{Research Article}

Keywords: leaf anatomical, functional traits, water deficit, adaptive strategies, environmental factors.

Posted Date: July 19th, 2021

DOl: https://doi.org/10.21203/rs.3.rs-211772/v1

License: (9) This work is licensed under a Creative Commons Attribution 4.0 International License.

Read Full License 


\section{Abstract}

The link between functional traits and changes in the environment are challenging, especially in systems of high diversity, such as transitional regions between savannas and tropical forests that are considered unstable and highly vulnerable to climate change. Here we evaluate a series of anatomical traits, key morphological traits, and nutrient concentration for the most representative woody species of four vegetation types (i.e. semideciduous seasonal forest, transition forest, typical cerrado and rocky cerrado) in the Amazonia-Cerrado transition. Our aim was to understand how trees respond to the distinct and unique environmental conditions in each area. Overall, species growing in closed-canopy environments exhibited acquisitive strategies (i.e., higher leaf water content and higher specific leaf area). On the other hand, species from open-canopy environments have adopted conservative strategies (i.e., higher leaf thickness and higher trichomes density). These differences represent a divergence in the adaptive strategies of woody species of the Amazonia-Cerrado transition and are important indicators of how vegetation can respond to future climate change and water availability. Despite these differences, stomatal density and leaf nutrient concentration at a mass basis was surprisingly similar across trees from all vegetation types, suggesting some common environmental drivers, such as likely similar nutrient limitation and climate seasonality.

\section{Introduction}

Trees display different ecological strategies in response to contrasting habitats under distinct environmental stresses (Borges et al. 2019). Ecological strategies are expressed as a balance between functional traits and the environment, driven by environmental constraints, which may favour different sets of traits (Wright et al. 2006). Functional traits are morpho-physiological-phenological characteristics that directly or indirectly affect plant performance through their effects on growth, survival, and reproduction (Violle et al. 2007). Such adaptations are essential for the survival and expansion of species ecological limits (Ghalambor et al. 2007), and are governed by modifications in leaf traits, which enable species to overcome different environmental filters (Borges et al. 2019), particularly associated with resource availability, such as water, nutrients, and light (Wellstein et al. 2017). The coordinated relationship between functional traits can be expressed in a gradient of strategies that ranges from fast acquisition to efficient resource conservation (Wright et al. 2004; Reich 2014). Functional traits linked to faster growth rate and higher productivity (acquisitive strategy) are favourable in environments with high water and light availability enhancing photosynthetic efficiency. In contrast, traits representing higher resource conservation and drought tolerance (i.e., conservative strategy), are widely reported in environments under water and nutritional deficits (Prado-Junior et al. 2016), reflecting the extremes of an ecological continuum (Grime 1965; Craine 2009).

It is commonly assumed that, in open-canopy vegetation types, such as typical cerrado and rocky cerrado, two subtypes of the Brazilian savanna, there is greater resource limitation (Bieras and Sajo 2009; De Paula et al. 2019) with high light intensity, high temperature and stronger water deficit, which generally favours stress-tolerant species (Hopper et al. 2016). In contrast, in closed-canopy vegetation types, such 
as forest formations in general, under lower light input, lower temperature there is higher water availability (Marimon-Junior and Haridasan 2005; Araújo et al. 2021b).

In the Amazonia-Cerrado transition, we can find contrasting vegetations side by side as is the case in our study, two are open-canopy (typical cerrado and rocky cerrado) and two are closed-canopy (semideciduous forest and transitional forest) that represent an open-air laboratory (Marimon-Junior and Haridasan 2005; Araújo et al. 2021a; b). These differences environmental may act together shaping tree leaf morphological and anatomical structures, leading to different leaf patterns between different vegetation types through time, as reported worldwide (Hoffmann et al. 2005; Rossatto et al. 2009; Dong et al. 2020; Anderegg et al. 2021).

Leaves are the most sensitive and environmentally adaptable organs ( $\mathrm{Li}$ and Bao 2014), being directly exposed to sunlight and high temperatures (Dickison 2000). In an environment under water limitation and high light intensities, plants tend to develop thicker leaves to avoid leaf tissue damage (Cornelissen et al. 2003; Rozendaal et al. 2006). Higher leaf thickness also allows species to increase water conservation and resistance to physical damage (Yates et al. 2010; Monteiro et al. 2016; Lin et al. 2017), reflecting in greater resource security. Lower investment in specific leaf area can help prevent water loss through transpiration and increase resource allocation to other plant organs (Laughlin et al. 2010; PérezHarguindeguy et al. 2013). Species from water limiting environments also tend to show distinctive anatomical traits, increasing stomatal density and reducing stomatal size, becoming more efficient controlling water loss to the atmosphere (Aasamaa et al. 2001; Golstein et al. 2008). On the other hand, in closed-canopy environments, species usually invest in higher specific leaf area to maximize light interception and with larger stomata to increase $\mathrm{CO}_{2}$ assimilation (Casas et al. 2011), which enhance photosynthetic efficiency (Cornelissen et al. 2003) and enable greater tree growth (Ogburn and Edwards 2010). In addition, leaf nutrient concentration reflects soil fertility and is an important determinant of the species performance in their habitats (Aerts and Chapin 1999), reflecting physiological needs and potential growth (Field and Mooney 1986).

Savannas and rainforests are the most important vegetation types in terms of area occupied on the planet, biodiversity, and carbon stock (Torello-Raventos et al. 2013). Between the two largest South American biomes, the Brazilian Savanna, known as the Cerrado, and the Amazonia, there are an extensive transitional area, the Cerrado-Amazonia transition, with unique characteristics, such as a shared floristic composition, edaphic and climatic parameters, and occurrence of fires, mainly in savanna formations (Furley and Ratter 1988; Ratter 1993; Marimon et al. 2006, 2014). These transitional regions are considered relatively unstable and may be highly susceptible to global climate change (Marimon et al. 2014; Morandi et al. 2018; Araújo et al. 2021a). The prediction regarding the climate is that a progressive increase of the temperature in the next decades (Gatti et al. 2014) will continue to occur, causing more frequent and more intense dry seasons (Coe et al. 2016). Furthermore, in this region, the photosynthetic functions of trees are affected by high temperatures, making photosystem II more vulnerable to ongoing and future climate changes, putting at risk the persistence of tree species over time (Tiwari et al. 2020; Araújo et al. 2021a). Therefore, understanding leaf morphological and anatomical patterns at the 
community level are fundamental to clarify how selective processes act on different species and to describe functional patterns (Pearson and Dawson 2003).

Our study aims to compare morpho-anatomical traits and leaf nutrient concentrations in distinct plant communities along a gradient with multiple environmental factors in the Cerrado-Amazonia transition. Here we introduce a set of ecologically important functional traits that promote new insights into the combination of leaf traits (e.g., stomata density, stomata size, maximum opening of stomata pore and trichomes density) in addition to morphological traits and concentration nutrients in the leaves that allow to understand the dimensions of the ecological strategies adopted by woody plants in different vegetation types.

The plant species occur along a gradient with multiple combined environmental factors (Marimon-Junior and Haridasan 2005; Araújo et al. 2021b). We wait for a gradient response in leaf traits from the vegetation more exposed to light, high temperature, and under stronger water limitation (rocky cerrado and typical cerrado) to the closed-canopy semideciduous seasonal forest. We hope that the cerradão (i.e., woodland savanna, from now on the transitional forest) will show intermediate patterns in leaf-level adaptations because it contains a mixture of forest and cerrado species (Marimon-Junior and Haridasan 2005; Marimon et al. 2014). Specifically, we hypothesize that community-level traits will display a gradient response going from functional traits linked to a faster growth rate and typical of closed-canopy environments (e.g. higher specific leaf area, higher leaf water mass content, higher leaf nutrient concentration and larger stomata) to functional traits linked to a slower growth rate and typical of opencanopy environments (e.g. higher trichomes density, higher leaf thickness, lower specific leaf area and lower leaf nutrient concentrations and smaller stomata) (Wright et al. 2004; Rossatto et al. 2009; Reich 2014; Monteiro et al. 2016; Araújo et al. 2021b).

\section{Material And Methods}

\section{Study area}

The four study areas are in Nova Xavantina, eastern Mato Grosso state, Central Brazil, in the AmazoniaCerrado transition zone (Figure 1). The climate is seasonal with two well-distinct periods, the rainy (October to March) and the dry (April to September), being Aw type, according to Köppen's classification (Alvares et al. 2013), with annual rainfall $1.600 \mathrm{~mm}$ and mean annual temperature of $25^{\circ} \mathrm{C}$ (Marimon et al. 2010). Three areas are located in the Municipal Park of Bacaba ( $14^{\circ} 41^{\prime} 09^{~ " S}$ and $\left.52^{\circ} 20^{\prime} 09^{\prime \prime} \mathrm{W}\right)$. Our vegetation gradient includes, the typical cerrado (open-canopy) is a subtype of cerrado stricto sensu and exhibits predominantly arboreal-shrubby vegetation, with a tree cover of 20 to $50 \%$ and heights between 3, 7 m (Ribeiro and Walter 2008; Mews et al. 2011; Gomes et al. 2016). It occurs on deep, well-drained, dystrophic, acidic Latosols (Ferralsols) and with high exchangeable aluminium contents (Marimon-Junior and Haridasan 2005). Rocky cerrado (open-canopy) is a savanna phytophysiognomy, occurs in shallow soils with rocky outcrops of the Neosol type, the flora in this phytophysiognomy is similar to the species of the typical cerrado (Gomes et al. 2016). The trees settle in the cracks between the rocks, where there is 
accumulation and decomposition of organic matter and sand deposition resulting from the weathering of the rocks (Maracahipes et al. 2011). Transitional forest (cerradão) is forest-type vegetation, with tall trees and closed-canopy (Marimon-Junior and Haridasan 2005; Reis et al. 2015) occurring in dystrophic soil, with higher percentages of clay that result in higher availability of water throughout the year for the trees. In addition, it features a mixture of forest and cerrado species (Marimon and Haridasan 2005; Marimon et al. 2014). The other study area is a semideciduous forest (closed-canopy), at Vera Cruz farm. The vegetation is characterized by typical Amazonia tall trees creating a shaded environment, and the soil is characterized by low acid plinthsols with lateritic outcrops and concretions (Marimon et al. 2014). The four vegetation areas together represent an open-air laboratory, ranging from open-canopy environments (rocky cerrado and typical cerrado) to the transitional forest (cerradão) can be considered intermediate vegetation type in this gradient, contains tall trees $<17 \mathrm{~m}$ and closed-canopy, to the taller trees $>25 \mathrm{~m}$ and completely closed-canopy vegetation (semideciduous forest), (Marimon and Haridasan 2005; Araújo et al. 2021a; b).

\section{Data collection}

We selected seven species that represented $(>80 \% \mathrm{IVI})$ in the plant communities in each vegetation type, according to the importance value index (IVI, Table 1), which considers species relative density, frequency, and dominance (Martins 1991). For each species, we sampled the five largest individuals and, for each one, we selected terminal branches completely exposed to the sun to avoid light variations throughout the day and we selected eight fully expanded tree canopy leaves or pathogen-free leaflets in the peak rainy period (February). We use five leaves to measure morphological traits and with the same leaves, we determine the concentration of foliar nutrients and we collect more three leaves to measure anatomical traits.

\section{Leaf morphological traits and nutrient analysis}

Functional traits assessed in this study are listed in Table 2. We measured leaf thickness $(\mathrm{mm})$ using an electronic digital micrometre $( \pm 0.001 \mathrm{~mm})$. Fresh leaves were scanned, and leaf area measured with ImageJ software (Abràmoff et al. 2004). We estimated the wet weight of the leaves with a precision balance $( \pm 0.001 \mathrm{~g})$, then placed them in paper bags in an oven at $60^{\circ} \mathrm{C}$, and after $72 \mathrm{~h}$ determined the dry weight. The leaf water content $\left(\mathrm{g} \mathrm{g}^{-1}\right)$ was calculated as the ratio between wet and dry weights. The specific leaf area $\left(\mathrm{cm}^{2} \mathrm{~g}^{-1}\right)$ was calculated as the ratio between leaf area and leaf dry mass (PérezHarguindeguy et al. 2013). Dried samples were sent to the laboratory of Soil Department of the Federal University of Viçosa (UFV, MG, Brazil), for nutrient concentration analyses. $\mathrm{N}$ and $\mathrm{P}\left(\mathrm{g} \mathrm{kg}^{-1}\right)$ were determined by Kjedahl digestion and UV-Vis spectroscopy, respectively, and the other nutrients (Ca, Mg and $\mathrm{K}, \mathrm{g} \mathrm{kg}^{-1}$ ) were determined by atomic absorption spectrometry.

\section{Leaf anatomical traits}

We sampled three leaves of each individual and, on abaxial and adaxial leaf surfaces, we applied the foliar surface imprinting method (Weyers and Johansen 1985) using high moulding technology silicone. 
After drying, we obtained reverse imprints from the moulds, using colourless nail polish and photographed the imprints on a light optical microscope (Zeiss Primo Star), with a coupled camera taken under microscopic magnification of 40x. We randomly selected 10 fields from each leaf and processed the images with Image J software (Abràmoff et al. 2004). The measured parameters were: guard cell length ("L" in $\mu \mathrm{m}$ ), guard cell pair width ("W", in $\mu \mathrm{m}$ ), stomata size ("S", estimated as $S=L$ * W, according to Franks et al. 2009a; b) and maximum area of the stomatal pore ("amax", in $\mu \mathrm{m}^{2}$ ). The maximum area of the stomatal pore was calculated as amax $=a * S$, where $a=0.12$, according to Franks and Beerling (2009). Stomata density $\left(\mathrm{mm}^{-2}\right)$ was calculated for each individual as the average number of stomata counted in a given area. The same area was used to calculate trichomes density $\left(\mathrm{mm}^{-2}\right)$, when present. A total of 25 stomata per individual were measured, and stomata densities, lengths, and widths were averaged per species.

\section{Statistical analysis}

All analyses were performed in R software (2019). Before performing all analyses, we tested the normality and homocedastity of the data using the Shapiro-Wilk and Levene tests (Levene 1961; Shapiro-Wilk 1965). All variables were log10-transformed when necessary. We created a variance partition to understand which organizational levels (species and individuals) best explain the variation of each functional traits and, for that, we used different groupings of linear models and adjusted the separate models for each functional traits (Rosas et al. 2019). We introduce species and individuals as nested random factors and vegetation type as (fixed factor) to analyze how the variation of functional traits are distributed among these organizational levels, and we use functional traits as the response variable for each of the models. To test for differences in functional traits between vegetation types, we compared the functional traits using Generalized Linear Mixed Models (GLMM) in the Ime4 package (Bates et al. 2014), with the vegetation type as predictors (fixed effect) and species as a random effect. We carried out a principal component analysis (correlation PCA), to investigate how leaf functional traits were distributed among tree communities. In order to estimate allometric lines of best fit for the bivariate relationships, we fitted standardized major axis and tested for differences in inclination (slopes) between the four vegetation types using SMATR package (Warton et al. 2012).

\section{Results}

For most of the leaf traits we measured, the largest variations were attributed to differences between species, ranging from $>65 \%$ of the variation explained by species differences for leaf nutrient concentration, $72 \%$ for morphological traits, and $70 \%$ for anatomical traits (Figure 2; Table S1). Individuallevel explained between 36 to $47 \%$ of the variation in $\mathrm{K}$ and the density and size of stomata (Figure 2).

Species that grow in closed-canopy environment generally showed different leaf traits compared to species that grow in open-canopy environments, except for leaf nutrient concentration at a mass basis (Table 3; Table S2). Species in the semideciduous forest showed higher specific leaf area and higher leaf water content (Table 3). Unexpectedly, species in the semideciduous forest showed the maximum area of 
the stomatal pore and stomatal size similar to species that grow in rocky cerrado (Table 3). On the other hand, species in open-canopy environments showed smaller SLA and thick leaves, combined with higher trichomes density (Table 3). At a mass basis $\left(\mathrm{mg} \mathrm{g}^{-1}\right)$, there was no diference between species from distinct vegetation types for leaf macronutrient concentrations (Table S2; Table S3). At an area basis, however, species growing in the semideciduous forest showed lower leaf concentration of $\mathrm{N}, \mathrm{P}$ and $\mathrm{Mg}$ compared to species in other vegetation types (Table 3). On the other hand, the species of the transitional forest, typical cerrado and rocky cerrado showed similar leaf nutrient concentrations (Table 3). There were no differences in leaf $\mathrm{K}$ and $\mathrm{Ca}$ concentration between vegetation types (Table 3; Table S4). Indeed, the major source of variability for all nutrients were within species (Figure 2).

The PCA explained $51 \%$ of the total data variation in the first two axes and the variation explained by the five axes contributed with $>80 \%$ (Table S5), and differences between the distinct plant communities reflected in clear discrimination between closed and open-canopy vegetation, revealed by PC2 (Figure 3), especially determined by higher leaf water content, stomata size, and maximum opening of the stomatal pore observed for species growing in semideciduous and transition forests.

Among individuals in all vegetation types, leaf $\mathrm{N}$ concentration was positively correlated with SLA (semideciduous forest: $\mathrm{R}^{2}=0.37, P=0.003$; transition forest: $\mathrm{R}^{2}=0.43, P=0.001$; typical cerrado: $\mathrm{R}^{2}=$ $0.22, P=0.030$; rocky cerrado: $\mathrm{R}^{2}=0.27, P=0.017$; Figure $4 a$ ). However, whereas semideciduous forest exhibit higher SLA at a given N, transition forest showed lowest SLA at a given N and the open-canopy vegetation (typical cerrado and rocky cerrado) showed intermediate intercepts (Wald $=46.39, P<0.0001$, Figure 4a). Stomata density was also positively related with leaf $\mathrm{N}$ concentration, but only for transition forest and rocky cerrado (transition forest: $\mathrm{R}^{2}=0.19, P=0.042$; rocky cerrado: $\mathrm{R}^{2}=0.24, P=0.023$; Figure 4b). There was also a positive relationship between leaf $P$ concentration and stomata size for the two closed-canopy communities (semideciduous forest: $\mathrm{R}^{2}=0.15, P=0.048$; transition forest: $\mathrm{R}^{2}=0.33, P=$ 0.006; Figure 4c). We did not find any relationship between anatomical traits, and there was no relationship between stomata density and stomata size for all data together or for each vegetation separately.

\section{Discussion}

Together, our findings support that the trees from distinct vegetation types exhibit strategies related to invest in water-saving (species open-canopy environments) and optimize carbon acquisition (species closed-canopy environments) (Rozendaal et al. 2006). The plant communities are under strong selective environmental pressure (Marimon et al. 2014) and, to survive in their habitat, these species developed distinct resource use adaptive strategies (Abrams et al. 1994; Araújo et al. 2021b).

The similarities in stomatal dimensions (i.e., stomatal density, the maximum area of the stomatal pore, and stomatal size) between leaves from closed-canopy and open-canopy trees can be explained by the strong effect of seasonal climate (Marimon et al. 2014), as Pearce et al. (2006) observed that stomatal dimensions are strongly associated with seasonal environments and reflect climate adaptations. In the 
rocky cerrado, where access to water and soil nutrients is more limited (Marimon and Haridasan 2005) we expected that the stomatal dimensions would be smaller than the values recorded in the semideciduous forest (Franco 2002; Pearce et al. 2006). However, in this case, it is possible that other morpho-anatomical strategies, such as the greater thickness leaves (Table 3 ) and the high occurrence of trichomes $\left(\sim 110 / \mathrm{mm}^{-2}\right)$ in the rocky cerrado and the total absence of trichomes in the leaves of the trees of the semideciduous forest compensated for the stomatal dimensions and resulted in very similar values between both vegetations, as in general, smaller stomatal dimensions are linked to a smaller amount of water available (Franco 2002; Rossatto et al. 2009; Araújo et al. 2021b).

Overall, species growing in closed-canopy environments exhibited acquisitive strategies (i.e., higher leaf water content and higher specific leaf area). On the other hand, species from open-canopy environments have adopted conservative strategies (i.e., higher leaf thickness and higher trichomes density), validating the economic spectrum leaf and reflecting the environmental differences between these vegetation types (Wright et al. 2004; Marimon and Haridasan 2005; Araújo et al. 2021b).

Larger stomata are commonly found in leaves of closed-canopy environments owin help to increase $\mathrm{CO}_{2}$ assimilation capacity and evapotranspiration rates, which consequently promote greater growth rates (Galmés et al. 2007; Ogburn and Edwards 2010), as recorded for transition forest in previous studies (Marimon et al. 2014). On the other hand, for the open-canopy vegetations (i.e., rocky cerrado and typical cerrado), species able to have a faster response to stronger seasonal water stress and higher tolerance to dystrophic soils, may have been favoured by natural selection (Franco 2002; Marimon-Junior and Haridasan 2005). In fact, smaller stomata, as found for species in the rocky cerrado and typical cerrado minimize water deficit and promote water use efficiency (Golstein et al. 2008). Also, smaller stomata are associated with plants growing in high irradiance levels and low air humidity, conditions normally observed in open-canopy environments (Bedetti et al. 2011; Araújo et al. 2021b), providing faster responses to reduced leaf transpiration (Rossatto et al. 2009).

We also found that species in the semideciduous forest invest in higher specific leaf area at a given leaf $\mathrm{N}$ concentration probably to overcome light competition by increasing the leaf area, light interception, and photosynthetic rates (Grime 1983; Cornelissen et al. 2003; Casas et al. 2011). If the light is the main limiting factor for species in forest environment (Carswell et al. 2000; Felfili et al. 2001; Montgomery and Chazdon 2002), from an evolutionary point of view, the investment in leaf area may be more advantageous, even considering that thinner leaves are more susceptible to herbivores or prone to water loss (Westoby et al. 2002). Unexpectedly, in our study semideciduous forest species showed the lowest $\mathrm{N}$ and $\mathrm{P}$ leaf concentration on an area basis, which may reflect a strong nutrient limitation in these forest soils (Marimon et al. 2014). Furthermore, species from open-canopy environments invested in higher leaf thickness that helps reduce leaf damage caused by herbivores and increase leaf lifespan (Grime 1983; Cornelissen et al. 2003; Bündchen et al. 2015). Interestingly, species from the transitional forest showed markedly similar traits compared to species from rocky cerrado and typical cerrado, such as low SLA, high TRD and LET, which indicate mixed strategies responding to mixed environmental drivers. These findings reinforce the idea that transitional forest is typical contact areas between savannas and forests 
(Ratter 1993; Ivanauskas et al. 2008), especially in the Amazonia-Cerrado transition (Marimon et al. 2014; Marques et al. 2020). These different combinations of ecological strategies in transitional forest can be advantageous in dealing with different environmental pressures, an essential condition for the persistence of species over time.

The positive relationship between $\mathrm{N}$ leaf tissue concentrations and stomata density for rocky cerrado and for transitional forest species may suggest a stronger pressure to optimize resources in these vegetations, particularly water and nitrogen, probably to maximize photosynthesis (Wright et al. 2003). Moreover, $\mathrm{P}$ and stomata size scaled positively, but only for forests formations, where plants should invest in primary growth to reach the canopy and successfully compete for light. Whereas P limitation is associated with lower wood density and greater hydraulic conductivity (Resco de Dios 2003), the coordination between $\mathrm{P}$ availability and stomata size (reflecting the anatomical adjustment to stomata opening control) in low-P soil and light-limited vegetation might be a key adaptation. Thus, the interaction between nutrients and water availability may have critical implications for the future distribution of plants and their responses to increasing drought severity and length (Cramer et al. 2009).

In addition, the relatively high trichomes density observed in rocky cerrado and typical cerrado species, may also reflect adaptation to control water deficit due increase water vapour concentration around the leaf boundary layer (Fahn and Cutler 1992; Larcher 2000). It is noteworthy that the combination of high temperature, high light incidence and low humidity of the air are determining factors influencing opencanopy environments species (Franco 2002; Araújo et al. 2021b). Trichomes are important adaptive strategies that help decrease light incidence and leaf temperature (Klich et al. 1997), which also promote water saving and concurrently avoid photoinhibition damage.

There was an overlap in leaf traits between all vegetation types analysed, which may be expected in a transition zone characterized by ecological tensions (Furley and Ratter 1988; Ratter 1993; Marimon et al. 2006 , 2014). Notably, the similar leaf nutrient concentration at a mass basis and similar stomata density between trees of all vegetation types suggest some common environmental drivers, such as likely similar nutrient limitation and climate seasonality. However, morphological and anatomical adjustments are associated with a strong connection between plant structures and functioning and we could find two major clusters with different ecological strategies, where trees from closed-canopy habitats optimize carbon acquisition, while trees in open-canopy environments invest in water-saving strategies (Bedetti et al. 2011). In this context, our hypothesis was partially supported.

Our findings suggest that trees from closed-canopy environments may be more vulnerable to drought events as they present a combination of functional traits that are less safe to deal with prolonged droughts, especially semideciduous forest species that share no traits to manage larger water balance during droughts and may suffer more from water stress. Even with similar STS and AMAX values to the rocky cerrado, this may not guarantee greater water security for semideciduous forest species, because they have low hydraulic safety margins and, therefore, are more susceptible to the risk of hydraulic failure compared to open-canopy environments species (Aasamaa et al. 2001; Hetherington and Woodward 
2003; Jancoski 2019). On the other hand, species from open-canopy environments are frequently exposed to water deficit and high temperatures and have developed a set of functional traits that are more resistant to drier and hotter conditions (Jancoski 2019; Araújo et al. 2021a; b).

In this region, where deforestation is accelerated, and the climate becomes increasingly drier and hotter (Jiménez-Muñoz et al. 2013; Haghtalab et al. 2020). Trees are vulnerable to global warming, which has negatively impacted physiological mechanisms and caused irreversible damage to photosystem II, exposing species beyond their physiological limits that are adapted (Araújo et al. 2020a) and may have severe consequences, such as changes in plant communities composition, structure and functioning. Therefore, processes such as water use efficiency will be critical for the survival of species that inhabit hot and dry regions (Hulme 2005). Thus, tree species that invest in resource storage and water-saving strategies can better cope with expected future climate change, especially in the Amazonia-Cerrado transition, where some of the warmest temperatures and fastest warming in the tropics have been recorded and trees are more likely to be affected by ongoing and future climate change (Tiwari et al. 2020; Araújo et al. 2020a; b). Thus, we suggest that key traits linked to water savings contribute to the functional stability of species that occur in this important Amazonia-Cerrado ecological tension zone and can potentially contribute to the persistence of plant communities over time.

\section{Declarations}

\section{Acknowledgements}

This research received financial support from the Coordination for the Improvement of Higher Education Personnel (Coordenação de Aperfeiçoamento de Pessoal de Nível Superior - CAPES), through the Program of Academic Cooperation - PROCAD (Proc. 88881.068430-2014-01) and from CNPq/PELD (Conselho Nacional de Desenvolvimento Científico e Tecnológico/Projetos Ecológicos de Longa Duração, Proc. 441244/2016-5). Coordenação de Aperfeiçoamento Pessoal de Nível Superior (CAPES) grant to I. Oliveras, Pequisador Visitante Especial (PVE - 223221/2014).

\section{Funding}

CAPES: PROCAD (88881.068430-2014-01) and PVE (223221/2014);

CNPq: PELD (441244/2016-5).

\section{Conflicts of interest/Competing interests}

Not applicable.

\section{Availability of data and material}

Not applicable.

\section{Code availability}


Not applicable.

\section{References}

1. Aasamaa K, Sõber A, Rahi M (2001) Leaf anatomical characteristics associated with shoot hydraulic conductance, stomatal conductance and stomatal sensitivity to changes of leaf water status in temperate deciduous trees. Funct Plant Biol 28: 765-774.

2. Abràmoff MD, Magalhães PJ, Ram SJ (2004) Image processing with ImageJ. Biophotonics Intern 11: 36-43.

3. Abrams MD, Kubiske ME, Mostoller SA (1994) Relating wet and dry year ecophysiology to leaf structure in contrasting temperate tree species. Ecology 75: 123-133.

4. Aerts R, Chapin FS (1999) The mineral nutrition of wild plants revisited: a re-evaluation of processes and patterns. Adv Ecol Res 30: 1-67.

5. Alvares CA, Stape JL, Sentelhas PC, Gonçalves JLM, Sparovek G (2013) Köppen climate classification map for Brazil. Meteorol Z 22: 711-728.

6. Anderegg LD, Loy X, Markham IP, Elmer CM, Hovenden MJ, HilleRisLambers J, Mayfield MM (2021) Aridity drives coordinated trait shifts but not decreased trait variance across the geographic range of eight Australian trees. New Phytologist 229: 1375-1387.

7. Araújo I, Marimon BS, Scalon MC, Fauset S, Junior BHM, Tiwari R, Galbraith DR, Gloor MU (2021a). Trees at the Amazonia-Cerrado transition are approaching high temperature thresholds. Environmental Research Letters 16: 034047.

8. Araújo I, Marimon BS, Scalon MC, Cruz WJ, Fauset S, Vieira TC, Galbraith DR, Gloor MU (2021b) Intraspecific variation in leaf traits facilitates the occurrence of trees at the Amazonia-Cerrado transition. Flora 279: 151829.

9. Bates D, Maechler M, Bolker B, Walker S (2014) Fitting Linear Mixed-Effects Models Using Ime4. Journal of Statistical Software 67: 1-48.

10. Bedetti CS, Aguiar DB, Jannuzzi MC, Moura MZ, Silveira FA (2011) Abiotic factors modulate phenotypic plasticity in an apomictic shrub Miconia albicans (SW.) Triana along a soil fertility gradient in a Neotropical savanna. Aust J Bot 59: 274-282.

11. Bieras AC, Das Graças Sajo M (2009) Leaf structure of the cerrado (Brazilian savanna) woody plants. Trees 23: 451-471.

12. Borges ER, Prado-Junior J, Santana LD et al (2019) Trait variation of a generalist tree species (Eremanthus erythropappus, Asteraceae) in two adjacent mountain habitats: savanna and cloud forest. Aust J Bot 66: 640-646.

13. Bündchen M, Boeger MRT, Reissmann CB (2015) Estrutura foliar de espécies lenhosas de dossel e sub-bosque em uma floresta subtropical do sul do Brasil. Iheringia Ser Bot 70: 105-114.

14. Carswell FE, Meier P, Wandelli EV, Bonates LCM (2000) Photosynthetic capacity in central Amazonian rain forest. Tree Physiol 20: 179-186. 
15. Casas RR, Vargas P, Pérez-corona E, Manrique E, García-verdugo C, Balaguer L (2011) Sun and shade leaves of Olea europaea respond differently to tree size, light availability and genetic variation. Funct Ecol 25: 802-812.

16. Coe MT, Silverio DV, Bustamante M, Macedo M, Shimbo J, Brando PM (2016) Feedbacks between land cover and climate changes in the Brazilian Amazon and Cerrado biomes. In: AGU Fall Meeting Abstracts.

17. Cornelissen TG, Fernandes W (2003) Insetos herbívoros e treeas de inimigos a parceiros? Ciência Hoje 32: 24-30.

18. Craine JM (2009) Resource strategies of wild plants. Princeton University Press, Princeton.

19. Cramer MD, Hawkins HJ, Verboom GA (2009) The importance of nutritional regulation of plant water flux. Oecologia 161: 15-24.

20. De Paula LF, Kolb RM, Porembski S, Silveira FA, Rossatto DR (2019) Rocks and leaves: Can anatomical leaf traits reflect environmental heterogeneity in inselberg vegetation? Flora 250: 91-98.

21. Dickison WC (2000) Integrative plant anatomy. Academic press, San Diego.

22. Dong N, Prentice IC, Wright IJ, Evans BJ, Togashi HF, Caddy-Retalic S, Lowe AJ (2020) Components of leaf-trait variation along environmental gradients. New Phytologist 228: 82-94.

23. Fahn A, Cutler DF (1992) Xerophytes. In: Spez (ed) Encyclopedia of Tree Anatomy. Editora, Berlin, pp 87-98.

24. Felfili JM, Franco AC, Fagg CW, Sousa-Silva JC (2001) Desenvolvimento inicial de espécies de mata de galeria. In: Ribeiro JF, Fonseca CEL, Sousa-Silva JC (eds) Cerrado: caracterização e recuperação de matas de galeria. Embrapa Cerrados, Planaltina, pp 779-811.

25. Field C, Mooney H (1986) Photosynthesis-nitrogen relationship in wild plants. On the Economy of Plant Form and Function. Cambridge University Press, Cambridge.

26. Franco AC (2002) Ecophysiology of woody trees. In: Oliveira OS (ed) The cerrados of Brazil. Marquis, Rio de Janeiro, pp 178-197.

27. Franks PJ, Drake PL, Beerling DJ (2009a) Plasticity in maximum stomatal conductance constrained by negative correlation between stomatal size and density: an analysis using Eucalyptus globulus. Plant Cell Environ 32: 1737-1748.

28. Franks PJ, Leitch IJ, Ruszala EM, Hetherington AM, Beerling DJ (2012b) Physiological framework for adaptation of stomata to $\mathrm{CO}_{2}$ from glacial to future concentrations. Philos T R Soc B 367: 537-546.

29. Furley PA, Ratter JA (1988) Soil resources and tree communities of central Brazilian cerrado and their development. J Biogeogr 15: 97-108.

30. Galmés J, Flexas J, Savé R, Medrano H (2007) Water relations and stomatal characteristics of Mediterranean plants with different growth forms and leaf habits: responses to water stress and recovery. Plant Soil 290: 139-155.

31. Gatti LV, Gloor M, Miller JB et al (2014) Drought sensitivity of Amazonian carbon balance revealed by atmospheric measurements. Nature 506: 76-80. 
32. Ghalambor CK, McKay JK, Carroll SP, Reznick DN (2007) Adaptive versus non-adaptive phenotypic plasticity and the potential for contemporary adaptation in new environments. Funct Ecol 21: 394407.

33. Golstein G, Meinzer FC, Bucci SJ, Scholz FG, Franco AC, Hoffmann WA (2008) Water economy of Neotropical savanna trees: six paradigms revisited. Tree Physiol 28: 395-404.

34. Gomes L, Maracahipes L, Reis SM, Marimon BS, Marimon-Junior BH, Lenza E (2016) Dynamics of the woody vegetation of two areas of Cerrado sensu stricto located on different substrates. Rodriguésia 67: 859-870.

35. Grime JP (1965) Shade tolerance in flowering plants. Nature 208: 161.

36. Grime JP (1983) Tree strategies and vegetation processes. The Pitman Press, Great Britain.

37. Haghtalab N, Moore N, Heerspink BP, Hyndman DW (2020) Evaluating spatial patterns in precipitation trends across the Amazon basin driven by land cover and global scale forcings. Theoretical and Applied Climatology 1:1-17.

38. Hetherington AM, Woodward FI (2003) The role of stomata in sensing and driving environmental change. Nature 424: 6951-901.

39. Hoffmann WA, Franco AC, Moreira MZ, Haridasa NM (2005) Specific leaf area explains differences in leaf traits between congeneric savanna and forest trees. Funct Ecol 19: 932-940.

40. Hopper SD, Silveira FA, Fiedler PL (2016) Biodiversity hotspots and Ocbil theory. Plant Soil 403: 167216.

41. Hulme PE (2005) "Adapting to climate change: is there scope for ecological management in the face of a global threat?" J Appl Ecol 42: 784-794.

42. Ivanauskas NM, Monteiro R, Rodrigues RR (2008) Classificação fitogeográficas das florestas do Alto Rio Xingu. Acta Amazon 38: 387-402.

43. Jancoski HS (2019) Características morfofuncionais de árvores em resposta à sazonalidade climática e herbivoria na transição Cerrado-Amazônia. Universidade do Estado de Mato Grosso $89 \mathrm{f}$.

44. Jiménez-Muñoz JC, Sobrino JA, Mattar C, Malhi Y (2013) Spatial and temporal patterns of the recent warming of the Amazon forest. Journal of Geophysical Research: Atmospheres 118: 5204-5215.

45. Klich MG, Brevedan RE, Villamil SC (1997) Leaf anatomy and ultrastructure of Poa ligularis after defoliation and water stress. Proceedings of the 18th International Grassland Congress 1: 37-38

46. Larcher W (2000) Ecofisiologia vegetal. Editora, São Carlos.

47. Laughlin DC, Leppert JJ, Moore MM, Sieg CH (2010) A multi-trait test of the leaf-height-seed plant strategy scheme with 133 species from a pine forest flora. Funct Ecol 24: 493-501.

48. Levene H (1961) Robust Tests for the equality of variance. Contributions to Probability and Statistics, California.

49. Li FL, Bao WK (2014) Elevational trends in leaf size of Campylotropis polyantha in the arid Minjiang River valley, SW China. J Arid Environ 108: 1-9. 
50. Lin H, Chen Y, Zhang H, Fu P, Fan Z (2017) Stronger cooling effects of transpiration and leaf physical traits of plants from a hot dry habitat than from a hot wet habitat. Funct Ecol 31: 2202-2211.

51. Marques EQ, Marimon-Junior BH, Marimon BS et al (2020) Redefining the Cerrado-Amazonia transition: implications for conservation. Biodivers Conserv 29: 1-17.

52. Marimon BS, Felfili JM, Lima EDS, Duarte WMG, Marimon-Júnior BH (2010) Environmental determinants for natural regeneration of gallery forest at the Cerrado/Amazonia boundaries in Brazil. Acta Amazon 40: 107-118.

53. Marimon BS, Marimon-Junior BH, Feldpausch TR et al (2014) Disequilibrium and hyperdynamic tree turnover at the forest savanna transition zone in southern Amazonia. Tree Ecol Divers 7: 281-292.

54. Marimon-Junior BH, Haridasan M (2005) Comparação da vegetação arbórea e características edáicas de um cerradão e um cerrado sensu stricto em áreas adjacentes sobre solo distróico no leste de Mato Grosso, Brasil. Acta Bot Bras 19: 913-926.

55. Marimon BS, Lima ES, Duarte TG, Chieragatto LC, Ratter JA (2006) Observation on the vegetation of Northeastern Mato Grosso, Brazil, IV. An analysis of the Cerrado-Amazonian Forest ecotone. Edinburgh J Bot 63: 323-341.

56. Martins FR (1991) Estrutura de uma floresta mesófila. Editora da Universidade Estadual de Campinas, Campinas.

57. Mews HA, Marimon BS, Maracahipes L, Franczak DD, Marimon-Junior BH (2011) Dinâmica da comunidade lenhosa de um Cerrado Típico na região Nordeste do Estado de Mato Grosso, Brasil. Biota Neotrop 11: 239-253.

58. Monteiro MV, Blanusa T, Verhoef A, Hadley P, Cameron RW (2016) Relative importance of transpiration rate and leaf morphological traits for the regulation of leaf temperature. Aust J Bot 64 : $32-44$.

59. Montgomery RA, Chazdon RL (2002) Light gradient partitioning by tropical tree seedlings in the absence of canopy gaps. Oecologia 131: 165-174.

60. Morandi PS, Marimon BS, Marimon-Junior BH et al (2018) Tree diversity and above-ground biomass in the South America Cerrado biome and their conservatiom implications. Biodivers Conserv 1: 18.

61. Ogburn RM, Edwards EJ (2010) The ecological water-use strategies of succulent trees. Adv Bot Res 55: $179-225$.

62. Pearson RG, Dawson TP (2003) Predicting the impacts of climate change on the distribution of species: are bioclimate envelope models useful? Global Ecol Biogeogr 12: 361-371.

63. Pearce DW, Millard S, Bray DF, Rood SB (2006) Stomatal characteristics of riparian poplar species in a semi-arid environment. Tree physiology 26: 211-218.

64. Pérez-Harguindeguy N, Diaz S, Gamier E, Lavorel S, Poorter H, Jaureguiberry P, Urcelay C (2013) New handbook for stand-ardised measurement of plant functional traits worldwide. Aust J Bot 61: 167234. 
65. Prado-Junior JA, Schiavini I, Vale VS, Raymundo D, Lopes SF, Poorter L (2016) Functional traits shape size-dependent growth and mortality rates of dry forest tree species. J Plant Ecol 10: 895-906.

66. Ratter JA (1993) Transition between cerrado and forest vegetation in Brazil. In: Furley PA, Proctor J, Ratter JA (eds) Nature and dynamics of forest-Savanna Boundaries. Chapman \& hall, London, pp 417-429.

67. R Development Core Team R (2019) Foundation for Statistical Computing, Vienna.

68. Reich PB (2014) The world-wide 'fast-slow' plant economics spectrum: a traits manifesto. J Ecol 102: $275-301$.

69. Reis SM, Lenza E, Marimon BS et al (2015) Post-fire dynamics of the woody vegetation of a savanna forest (Cerradão) in the Cerrado-Amazon transition zone. Acta Bot Bras 29: 408-416.

70. Resco de Dios V, Turnbull MH, Barbour MM, Ontedhu J, Ghannoum O, Tissue DT (2013) Soil phosphorus and endogenous rhythms exert a larger impact than $\mathrm{CO}_{2}$ or temperature on nocturnal stomatal conductance in Eucalyptus tereticornis. Tree Physiol 33: 1206-1215.

71. Ribeiro JF, Walter BMT (2008) As principais fitofisionomias do bioma Cerrado. Cerrado: ecologia e flora 1: 151-212.

72. Rossatto, DR, Hoffmann WA, Franco AC (2009) Características estomáticas de pares congenéricos de cerrado e mata de galeria crescendo numa região transicional no Brasil Central. Acta Bot Bras 23: 499-508.

73. Rosas T, Mencuccini M, Barba J, Cochard H, Saura-Mas S, Martínez-Vilalta J (2019) Adjustments and coordination of hydraulic, leaf and stem traits along a water availability gradient. New Phytologist 223: 632-646.

74. Rozendaal DMA, Hurtado VH, PoorteR L (2006) Plasticity in leaf traits of 38 tropical tree species in response to light; relationships with light demand and adult stature. Funct Ecol 20: 207-216.

75. Shapiro SS, Wilk MB (1965) An analysis of variance test for normality (complete samples). Biometrika 52: 591-611.

76. Tiwari R, Gloor E, da Cruz WJA et al (2020) Photosynthetic quantum efficiency in south-eastern Amazonian trees may be already affected by climate change. Plant Cell Environ: 1-12.

77. Torello-Raventos M, Feldpausch TR, Veenendaal E et al (2013) On the delineation of tropical vegetation types with an emphasis on forest/savanna transitions. Plant Ecol Divers 6: 101-137.

78. Violle C, Navas ML, Vile D, Kazakou E, Fortunel C, Hummel I, Garnier E (2007) Let the concept of trait be functional. Oikos 116: 882-892.

79. Wellstein C, Poschlod P, Gohlke A, Chelli S, Campetella G, Rosbakh, S, Beierkuhnlein C (2017) Effects of extreme drought on specific leaf area of grassland species: A meta-analysis of experimental studies in temperate and sub-Mediterranean systems. Global Change Biol 23: 2473-2481.

80. Westoby M, Falster DS, Moles AT, Vesk PA, Wright IJ (2002) Tree ecological strategies: some leading dimensions on variation between species. Annu Rev Ecol S 33: 125-159. 
81. Weyers JDB, Johansen LG (1985) Accurate estimation of stomatal aperture from silicone rubber impressions. New Phytol 101: 109-115.

82. Warton, DI, Duursma, RA, Falster, DS, Taskinen S (2012) Smatr 3-an R package for estimation and inference about allometric lines. Methods Ecol Evol 3: 257-259.

83. Wright IJ, Ackerly DD, Bongers F, Harms KE, Ibarra-Manriquez G, Martinez-Ramos M, Poorter L (2006) Relationships among ecologically important dimensions of plant trait variation in seven Neotropical forests. Ann Bot 99: 1003-1015.

84. Wright IJ, Reich P, Westoby M. (2003) Least-Cost Input Mixtures of Water and Nitrogen for Photosynthesis. Am Nat 161: 98-111.

85. Wright IJ, Reich PB, Westoby M. (2004) The worldwide leaf economics spectrum. Nature 428: 821827.

86. Yates MJ, Verboom GA, Rebelo AG, Cramer MD (2010) Ecophysiological significance of leaf size variation in Proteaceae from the Cape Floristic Region. Funct Ecol 24: 485-492.

\section{Tables}

Table 1. Trees in distinct vegetation types in the Amazonia-Cerrado transition and their respective importance value index (IVI), calculated based on species relative density, frequency and dominance. The methodology adopted in the phytosociological surveys can be consulted in (Mews et al. 2011; Marimon et al. 2014; Reis et al. 2015; Gomes et al. 2016). 


\begin{tabular}{|c|c|c|}
\hline Species & Family & IVI \\
\hline \multicolumn{3}{|l|}{ Rocky Cerrado } \\
\hline Vatairea macrocarpa (Benth.) Ducke & Fabaceae & 13.66 \\
\hline Kielmeyera rubriflora Cambess. & Calophyllaceae & 9.42 \\
\hline Heteropterys byrsonimifolia A.Juss. & Malpighiaceae & 10.14 \\
\hline Erythroxylum suberosum A.St.-Hil. & Erythroxylaceae & 13.66 \\
\hline Qualea parviflora Mart. & Vochysiaceae & 17.94 \\
\hline Eugenia aurata O.Berg & Myrtaceae & 7.73 \\
\hline Anacardium occidentale L. & Anacardiaceae & 10.60 \\
\hline \multicolumn{3}{|l|}{ Typical Cerrado } \\
\hline Roupala montana Aubl. & Proteaceae & 14.66 \\
\hline Euplassa inaequalis (Pohl) Engl. & Proteaceae & 6.27 \\
\hline Guapira graciliflora (Mart. ex Schmidt) Lundell & Nyctaginaceae & 10.50 \\
\hline Qualea grandiflora Mart. & Vochysiaceae & 9.24 \\
\hline Qualea parviflora Mart. & Vochysiaceae & 20.55 \\
\hline Eriotheca gracilipes (K.Schum.) A.Robyns & Malvaceae & 7.29 \\
\hline Davilla elliptica A.St.-Hil. & Dilleniaceae & 15.07 \\
\hline \multicolumn{3}{|l|}{ Transition Forest } \\
\hline Tachigali vulgaris L.G.Silva \& H.C.Lima & Fabaceae & 34.44 \\
\hline Hirtella glandulosa Spreng. & Chrysobalanaceae & 44.28 \\
\hline Myrcia splendens (Sw.) DC. & Myrtaceae & 15.20 \\
\hline Tapirira guianensis Aubl. & Anacardiaceae & 16.15 \\
\hline Eriotheca gracilipes (K.Schum.) A.Robyns & Malvaceae & 7.97 \\
\hline Emmotum nitens (Benth.) Miers & Metteniusaceae & 13.89 \\
\hline Xylopia aromatica (Lam.) Mart. & Annonaceae & 14.91 \\
\hline \multicolumn{3}{|l|}{ Semideciduous Forest } \\
\hline Ephedranthus parviflorus S.Moore & Annonaceae & 33.18 \\
\hline Tetragastris altissima (Aubl.) Swart & Burseraceae & 24.51 \\
\hline Brosimum rubescens Taub. & Moraceae & 11.31 \\
\hline
\end{tabular}




\begin{tabular}{|lll|} 
Mabea fistulifera Mart. & Euphorbiaceae & 26.71 \\
\hline Cheiloclinium cognatum (Miers) A.C.Sm. & Celastraceae & 24.14 \\
\hline Amaioua guianensis Aubl. & Rubiaceae & 26.69 \\
\hline Chaetocarpus echinocarpus (Baill.) Ducke & Peraceae & 30.61 \\
\hline
\end{tabular}

Table 2. Morpho-anatomical traits and leaf nutrient concentration of trees in distinct vegetation types in the Amazonia-Cerrado transition.

\begin{tabular}{lll} 
Traits & Acronym & Unit \\
\hline Leaf nitrogen & $\mathrm{N}$ & $\mathrm{g} \mathrm{cm}^{-2}$ \\
\hline Leaf phosphorus & $\mathrm{P}$ & $\mathrm{g} \mathrm{cm}^{-2}$ \\
\hline Leaf potassium & $\mathrm{K}$ & $\mathrm{g} \mathrm{cm}^{-2}$ \\
\hline Leaf calcium & Ca & $\mathrm{g} \mathrm{cm}^{-2}$ \\
\hline Leaf magnesium & $\mathrm{Mg}$ & $\mathrm{g} \mathrm{cm}^{-2}$ \\
\hline Specific leaf area & $\mathrm{SLA}$ & $\mathrm{cm}^{2} \mathrm{~g}^{-1}$ \\
\hline Leaf thickness & LET & $\mathrm{mm}^{-1}$ \\
\hline Leaf water content & LWC & $\mathrm{g} \mathrm{g}^{-1}$ \\
\hline Trichomes density & TRD & $\mathrm{mm}^{-2}$ \\
\hline Stomata density & STD & $\mathrm{mm}^{-2}$ \\
\hline Stomata size & STS & $\mu \mathrm{m}^{2}$ \\
\hline Maximum opening of the stomatal pore & AMAX & $\mu \mathrm{m}^{2}$
\end{tabular}

Table 3. Morpho-anatomical traits and leaf nutrient concentration evaluated for trees in distinct vegetation types in the Amazonia-Cerrado transition. Leaf nitrogen $\left(\mathrm{N}, \mathrm{g} \mathrm{cm}^{-2}\right)$, leaf phosphorus $\left(\mathrm{P}, \mathrm{g} \mathrm{cm}^{-}\right.$ ${ }^{2}$ ), leaf potassium $\left(\mathrm{K}, \mathrm{g} \mathrm{cm}^{-2}\right)$, leaf calcium $\left(\mathrm{Ca}, \mathrm{g} \mathrm{cm}^{-2}\right)$, leaf magnesium $\left(\mathrm{Mg}, \mathrm{g} \mathrm{cm}^{-2}\right)$, specific leaf area $\left(\mathrm{SLA}, \mathrm{cm}^{2} \mathrm{~g}^{-1}\right)$, leaf thickness (LET, $\left.\mathrm{mm}\right)$, leaf water content $\left(\mathrm{LWC}, \mathrm{g} \mathrm{g}^{-1}\right)$, stomata density (STD, $\mathrm{mm}^{-}$ $\left.{ }^{2}\right)$, stomata size (STS, $\left.\mu \mathrm{m}\right)$, trichomes density $\left(\mathrm{TRD}, \mathrm{mm}^{-2}\right)$ and maximum opening of the stomatal pore $\left(\right.$ AMAX,$\left.\mu \mathrm{m}^{2}\right) . \mathrm{sd}=$ standard deviation and absent $(-)$, different lowercase letters denote significant differences (Tukey, $P<0.05$ ). Vegetation types: $\mathrm{SF}=$ semideciduous forest, $\mathrm{TF}=$ transitional forest, $\mathrm{TC}=$ typical cerrado, $\mathrm{RC}=$ rocky cerrado. 


\begin{tabular}{lllll} 
Traits & $\begin{array}{l}\text { SF } \\
\text { Average } \pm \text { sd }\end{array}$ & $\begin{array}{l}\text { TF } \\
\text { Average } \pm \text { sd }\end{array}$ & $\begin{array}{l}\text { TC } \\
\text { Average } \pm s d\end{array}$ & $\begin{array}{l}\text { RC } \\
\text { Average } \pm s d\end{array}$ \\
\hline STD & $246.95 \pm 55.16 \mathrm{a}$ & $181.40 \pm 100.96 \mathrm{a}$ & $153.31 \pm 89.88 \mathrm{a}$ & $240.86 \pm 74.95 \mathrm{a}$ \\
\hline STS & $106.76 \pm 66.34 \mathrm{~b}$ & $165.81 \pm 70.86 \mathrm{a}$ & $85.36 \pm 54.06 \mathrm{~b}$ & $77.57 \pm 69.01 \mathrm{~b}$ \\
\hline AMAX & $12.81 \pm 7.96 \mathrm{~b}$ & $19.89 \pm 8.50 \mathrm{a}$ & $10.24 \pm 6.48 \mathrm{~b}$ & $9.30 \pm 8.28 \mathrm{~b}$ \\
\hline SLA & $97.10 \pm 21.08 \mathrm{a}$ & $67.50 \pm 18.65 \mathrm{~b}$ & $72.51 \pm 23.11 \mathrm{~b}$ & $75.42 \pm 13.85 \mathrm{~b}$ \\
\hline LET & $0.168 \pm 0.02 \mathrm{c}$ & $0.292 \pm 0.06 \mathrm{~b}$ & $0.335 \pm 0.06 \mathrm{a}$ & $0.286 \pm 0.05 \mathrm{~b}$ \\
\hline LWC & $720.68 \pm 91.44 \mathrm{a}$ & $772.09 \pm 154.76 \mathrm{a}$ & $482.66 \pm 81.47 \mathrm{c}$ & $576.74 \pm 135.17 \mathrm{~b}$ \\
\hline TRD & $(-) \mathrm{c}$ & $75.27 \pm 89.93 \mathrm{ab}$ & $47.44 \pm 26.03 \mathrm{~b}$ & $109.51 \pm 71.87 \mathrm{a}$ \\
\hline Leaf N & $1.87 \pm 0.36 \mathrm{~b}$ & $2.80 \pm 0.60 \mathrm{a}$ & $2.16 \pm 0.81 \mathrm{~b}$ & $2.22 \pm 0.53 \mathrm{~b}$ \\
\hline Leaf P & $0.07 \pm 0.01 \mathrm{~b}$ & $0.12 \pm 0.03 \mathrm{a}$ & $0.11 \pm 0.05 \mathrm{a}$ & $0.14 \pm 0.05 \mathrm{a}$ \\
\hline Leaf $\mathrm{K}$ & $0.54 \pm 0.18 \mathrm{a}$ & $0.71 \pm 0.23 \mathrm{a}$ & $0.74 \pm 0.31 \mathrm{a}$ & $0.69 \pm 0.23 \mathrm{a}$ \\
\hline Leaf $\mathrm{Ca}$ & $0.49 \pm 0.30 \mathrm{a}$ & $1.10 \pm 1.04 \mathrm{a}$ & $0.56 \pm 0.33 \mathrm{a}$ & $0.41 \pm 0.13 \mathrm{a}$ \\
\hline Leaf $\mathrm{Mg}$ & $0.22 \pm 0.07 \mathrm{c}$ & $0.42 \pm 0.22 \mathrm{ab}$ & $0.56 \pm 0.34 \mathrm{a}$ & $0.33 \pm 0.12 \mathrm{bc}$
\end{tabular}

\section{Figures}



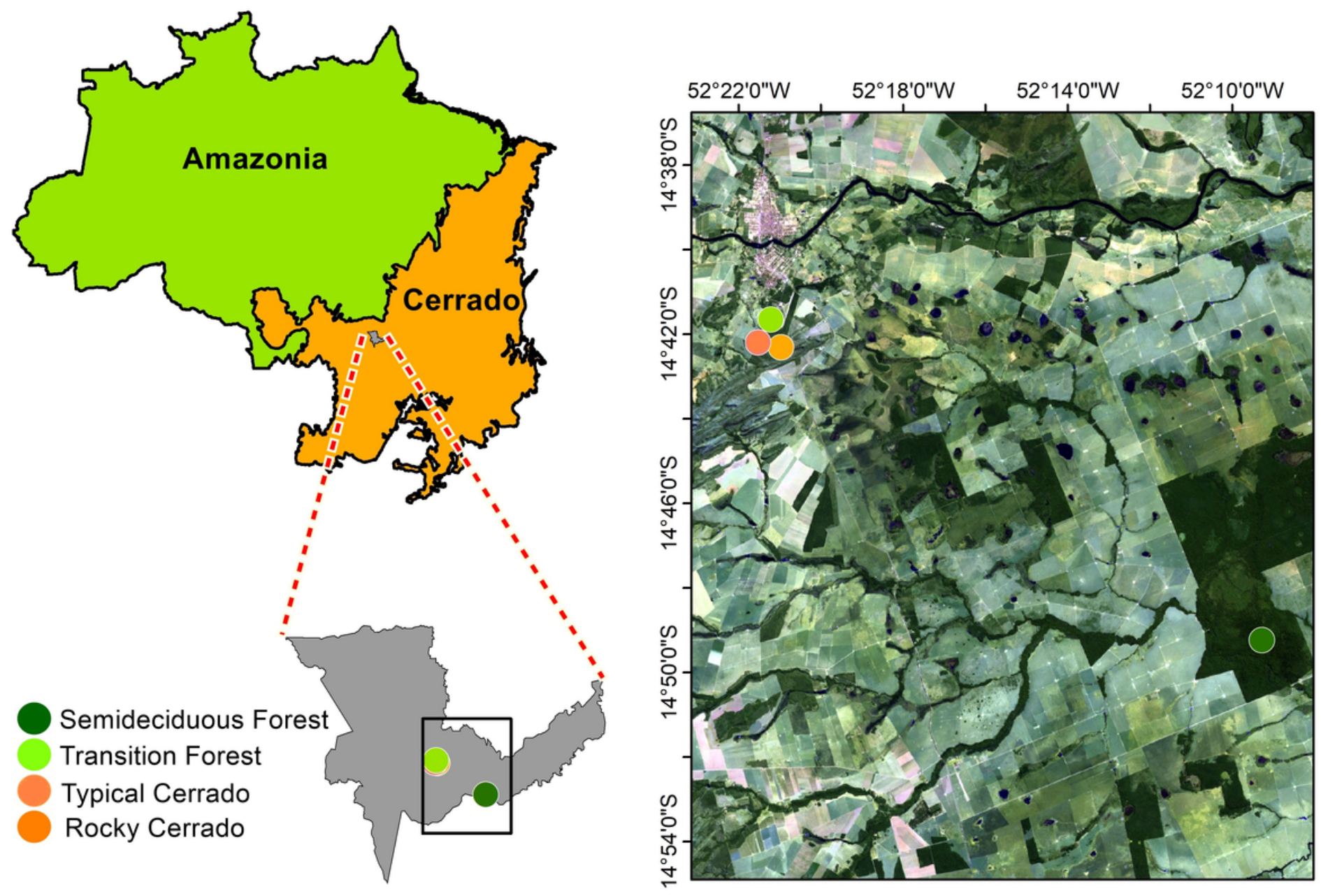

\section{Figure 1}

Distinct vegetation types in the Amazonia-Cerrado transition. Open-canopy vegetation (typical cerrado and rocky cerrado) and closed-canopy vegetation (semideciduous forest and transition forest/cerradão). 


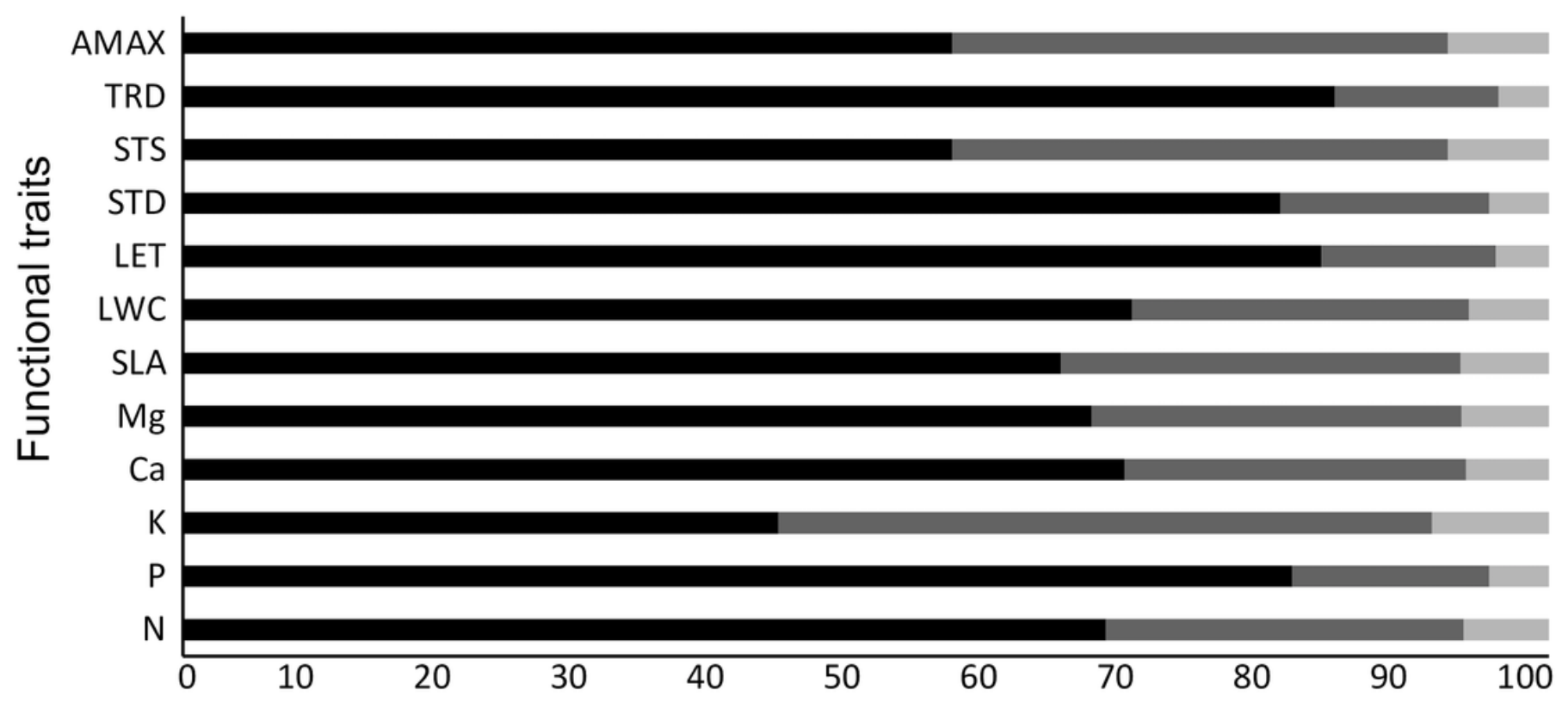

Species $\square$ Individual $\square$ Within

\section{Figure 2}

Partitioning of the variance of the nested linear models of the morpho-anatomical traits and leaf nutrient concentration of trees in distinct vegetation types in the Amazonia-Cerrado transition. Leaf nitrogen (N), leaf phosphorus $(P)$, leaf potassium $(K)$, leaf calcium $(\mathrm{Ca})$, leaf magnesium $(\mathrm{Mg})$, specific leaf area (SLA), leaf thickness (LET), leaf water content (LWC), trichomes density (TRD), stomata density (STD), stomata size (STS) and maximum opening of the stomatal pore (AMAX). Within means the residual error, all data were transformed (log-10) before analysis. 


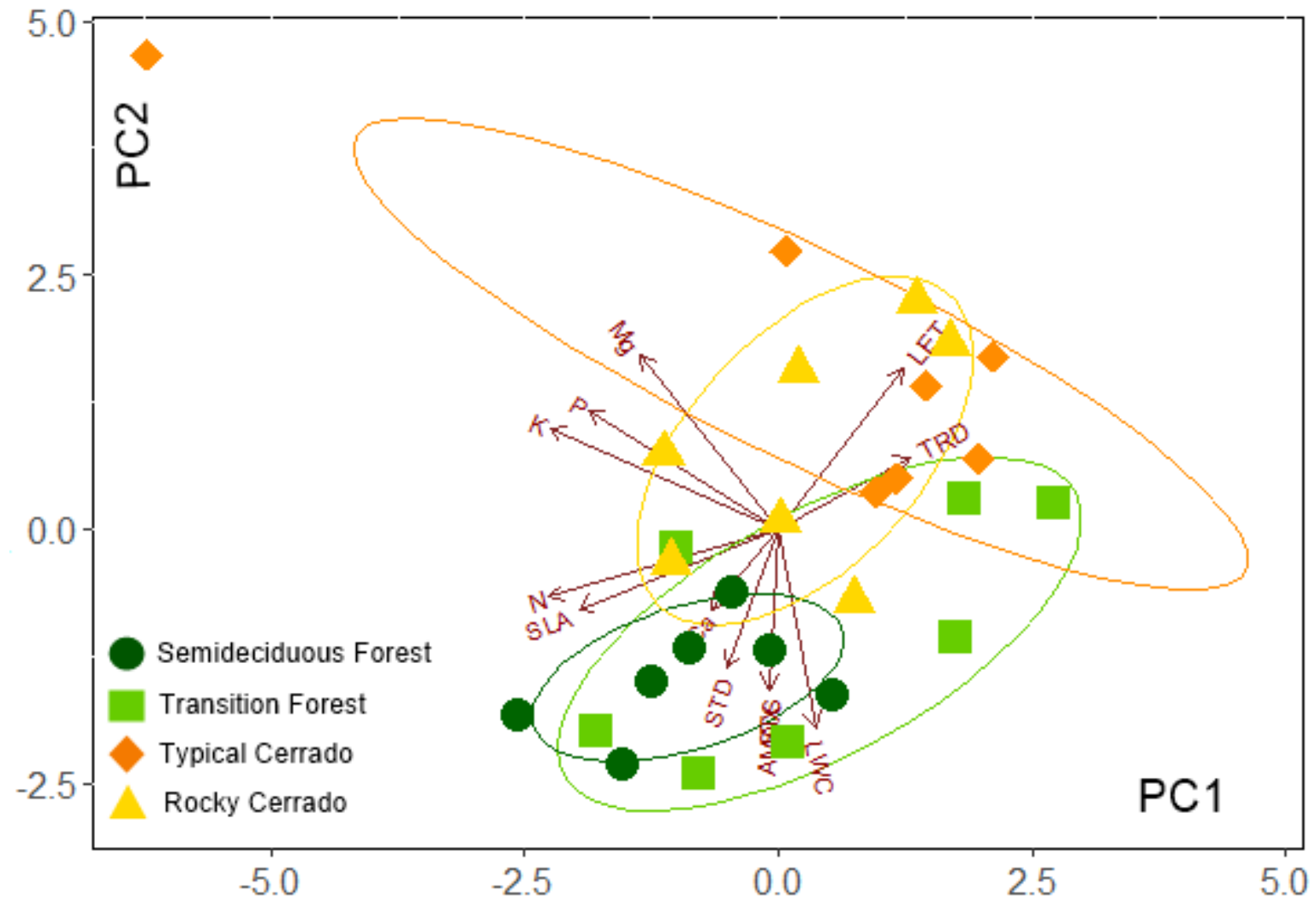

\section{Figure 3}

Principal component analysis (PCA) relating the leaf traits of trees in distinct vegetation types in the Amazonia-Cerrado transition. Leaf nitrogen $(N)$, leaf phosphorus $(P)$, leaf potassium $(K)$, leaf calcium (Ca), leaf magnesium (Mg), specific leaf area (SLA), leaf thickness (LET), leaf water content (LWC), trichomes density (TRD), stomata density (STD), stomata size (STS) and maximum opening of the stomatal pore (AMAX). We use species as a sampling unit. 

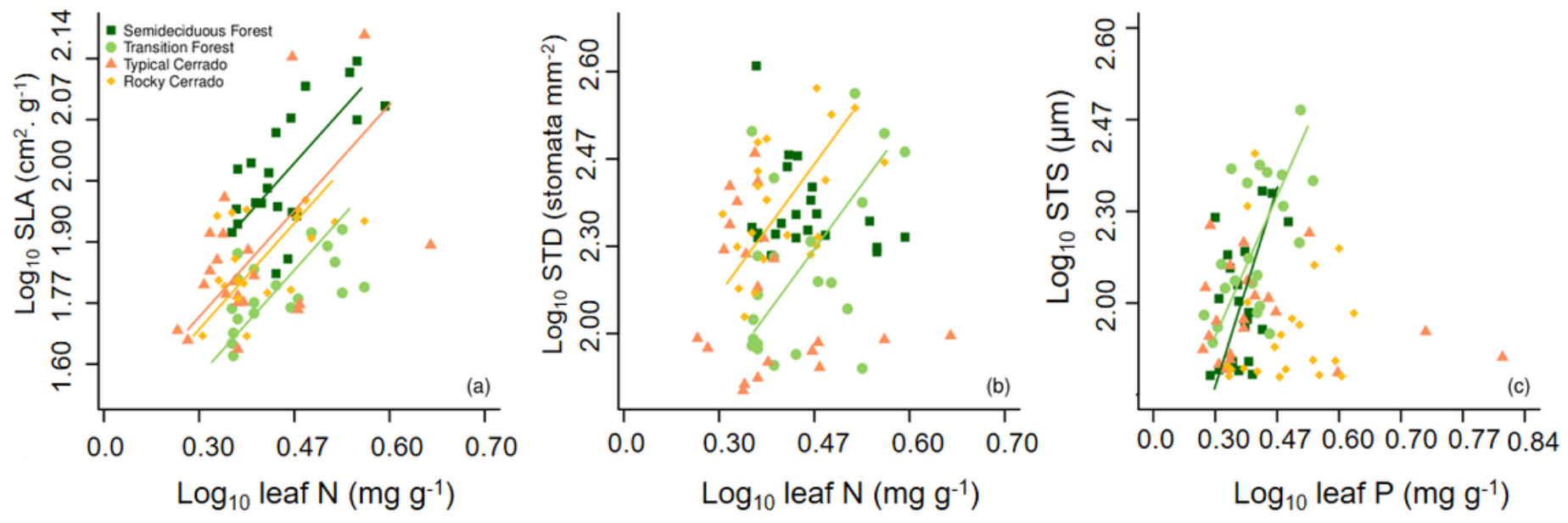

\section{Figure 4}

Bi-variate relationships between leaf nutrient concentration and morpho-anatomical traits of trees in distinct vegetation types in the Amazonia-Cerrado transition. Leaf nitrogen $(N)$, leaf phosphorus $(P)$, specific leaf area (SLA), stomata density (STD) and stomata size (STS). All data were transformed (log10) before analysis.

\section{Supplementary Files}

This is a list of supplementary files associated with this preprint. Click to download.

- Supplementarymaterial.docx 